\title{
A review of 17 cases of carcinoma of the thyroid and phaeochromocytoma
}

\author{
E. D. WILLIAMS ${ }^{1}$
}

From the Bernhard Baron Institute of Pathology, The London Hospital

SYNOPSIS The salient features of 15 cases of carcinoma of the thyroid and phaeochromocytoma. taken from the literature and two personal cases are reviewed. The significant points noted are the frequency with which the adrenal tumours were bilateral, the frequency with which a family history of phaeochromocytoma (six cases) and thyroid carcinoma (four cases) was present, and the frequencyt with which the type of thyroid tumour was medullary carcinoma.

In four of the 15 published cases the thyroid tumour was described as being medullary. Two personal cases both had medullary carcinoma of the thyroid, and this was also the type of thyroid? carcinoma present in five of the published cases in which the thyroid histology was personally $\overrightarrow{3}$ reviewed, making a total of 11 medullary carcinomas out of 17 cases. At least one other tumour was probably medullary, judging by the histological description. It is suggested that the association between phaeochromocytoma and thyroid carcinoma is specifically with medullary carcinoma of the thyroid.

Both personal cases showed multiple neural tumours; and because of this and the associatione with phaeochromocytoma the possible neural origin of medullary carcinoma of the thyroid is briefly discussed.

The occurrence in a few cases of parathyroid tumours has raised the possibility that these cases are related to the multiple endocrine adenoma syndrome. The dissimilarity between the cases with medullary carcinoma of the thyroid and phaeochromocytoma and those cases with ademonas involving pituitary, parathyroid, adrenal cortex and pancreatic islets is stressed. The term 'medullary? tumour syndrome' is suggested as a convenient non-committal name for this association of medullary? carcinoma of the thyroid with tumours of the adrenal medulla.

The association of thyroid carcinoma and phaeochromocytoma has been described in a number of isolated case reports over the last 30 years. These are both rather uncommon conditions, although neither is exceptionally rare, and the single fact of their association in a small number of cases is not by itself necessarily of any significance. The opportunity of studying two further cases of thyroid carcinoma and phaeochromocytoma stimulated interest in this association and led to a review of the previously reported cases. It is the purpose of this communication to stress certain features that suggest that this is not a chance combination of unusual conditions but an association of genetically determined tumours that throws some light on the nature and origin of the thyroid carcinoma.

${ }^{1}$ Present address: Department of Pathology, Postgraduate Medical School, Hammersmith Hospital, London.

Received for publication 20 August 1964.
The findings in these 17 cases in relation to thes phaeochromocytoma are set out in Table I. It can be seen that of the 17 cases 11 are female and six male? with an overall mean age of 35 years. These figures are not notably different from the age and sex incidence of uncomplicated phaeochromocytoma However, the adrenal findings differ markedly from? an unselected group of cases of phaeochromocytoma $N$ Of the 17 cases, 10 were bilateral. Of the 12 cases for which necropsy evidence was available, nine showed bilateral phaeochromocytoma; in two cases both adrenals contained tumour but the presence of bilateral phaeochromocytoma was not established $\stackrel{\rho}{+}$ In only one of the 12 necropsied cases (no. 10) is oneo adrenal presumed to be normal. For comparison the overall incidence of bilateral tumour is given bs Hume (1960), in a review of over 600 cases of phaeo $\Omega$ chromocytoma, as $9 \%$ of all cases. Familial phaeochromocytoma is uncommon; Hume listed only $2 \bar{z}^{2}$ 
TABLE I

DETAILS OF 17 CASES OF PHAEOCHROMOCYTOMA IN THE LITERATURE

\begin{tabular}{|c|c|c|c|c|c|c|}
\hline Case No. & Author & $\begin{array}{l}\text { Age at Diagnosis of } \\
\text { Phaeochromocytoma }\end{array}$ & Sex & $\begin{array}{l}\text { Necropsy } \\
\text { Performed }\end{array}$ & $\begin{array}{l}\text { Site of Phaeo- } \\
\text { chromocytoma }\end{array}$ & $\begin{array}{l}\text { Family History of } \\
\text { Phaeochromocytoma }\end{array}$ \\
\hline 1 & Eisenberg and Wallerstein (1932) & 63 & $\mathbf{F}$ & Yes & Bilateral ${ }^{1}$ & \\
\hline 2 & Beer et al. (1937) & 26 & $\mathbf{F}$ & No & Left & $\begin{array}{l}\text { Sister? phaeochromo- } \\
\text { cytoma at age of } 28\end{array}$ \\
\hline 3 & Muntz et al. (1947) & 39 & $\mathbf{F}$ & Yes & Bilateral & \\
\hline 4 & Rothermich (1952) & 25 & $\mathbf{F}$ & Yes & Bilateral & \\
\hline 5 & Dick et al. (1955) & 49 & $\mathbf{M}$ & No & Left & \\
\hline 6 & Freedman et al. (1958) & 34 & $\mathbf{F}$ & Yes & Left $^{2}$ & \\
\hline 7 & De Graeff et al. (1959) & 37 & $\mathbf{F}$ & Yes & Bilateral $^{3}$ & \\
\hline 8 & Smits and Huizinga (1961) & 62 & $\mathbf{M}$ & Yes & Bilateral & $\begin{array}{l}\text { Member of family with } \\
\text { multiple cases of phaeo- } \\
\text { chromocytoma }\end{array}$ \\
\hline 9 & Sipple (1961) & 33 & $\mathbf{M}$ & Yes & Bilateral & \\
\hline 10 & Cushman (1962) & 55 & $\mathbf{M}$ & Yes & Right & Son is case 11 \\
\hline 11 & Cushman (1962) & 32 & $\mathbf{M}$ & No & Left & Father is case 10 \\
\hline 12 & Sahay (1962) & 29 & $\mathbf{F}$ & Yes & Bilateral & \\
\hline 13 & Manning et al. (1963) & 18 & $\mathbf{F}$ & No & Bilateral & $\begin{array}{l}\text { Two sibs with bilateral } \\
\text { phaeochromocytoma }\end{array}$ \\
\hline 14 & Finegold and Haddad (1963) & 27 & $\mathbf{M}$ & Yes & Bilateral & $\begin{array}{l}\text { Father also bilateral } \\
\text { phaeochromocytoma }\end{array}$ \\
\hline 15 & Hayles et al. (1963) & 31 & $\mathbf{F}$ & Yes & Bilateral & \\
\hline 16 & Williams and Pollock (1964) & 34 & $\mathbf{F}$ & No & Left & \\
\hline 17 & Williams and Pollock (1964) & 19 & $\mathbf{F}$ & Yes & Bilateral & \\
\hline
\end{tabular}

Malignant

${ }^{2}$ Tumour of right adrenal interpreted as metastasis of thyroid carcinoma

${ }^{3}$ Also several parangangliomata

TABLE II

FINDINGS RELATING TO THE THYROID AND PARATHYROID IN 17 CASES SET OUT IN TABLE I

$\begin{array}{lllll}\text { Case Age at Diagnosis Sex } & \begin{array}{l}\text { Reported Histology of } \\ \text { Thyroid Carcinoma }\end{array} & \begin{array}{l}\text { Reviewed Histology of } \\ \text { Thyroid Carcinoma }\end{array} & \begin{array}{l}\text { Family History of } \\ \text { Thyroid Carcinoma }\end{array}\end{array}$

Carcinoma

\begin{tabular}{|c|c|c|c|c|c|c|c|}
\hline & & & & & & & 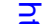 \\
\hline 1 & 63 & $\mathbf{F}$ & $\begin{array}{l}\text { Papillary adeno- } \\
\text { carcinoma }\end{array}$ & & & & $\ddot{-}$ \\
\hline 2 & 17 & $\mathbf{F}$ & Adenocarcinoma & & $\begin{array}{l}\text { Mother and two sisters } \\
\text { had thyroidectomy, ? } \\
\text { cause }\end{array}$ & & $\begin{array}{l}\frac{0}{0} \\
\frac{0}{2}\end{array}$ \\
\hline 3 & 33 & $\mathbf{F}$ & $\begin{array}{l}\text { Small clumps of cells } \\
\text { with dense fibrous stroma }\end{array}$ & & & $\begin{array}{l}\text { Two parathyroids, each } \\
2 \times 2 \times 4 \mathrm{~mm} \text {., seen }\end{array}$ & 공. \\
\hline 4 & 20 & $\mathbf{F}$ & Adenocarcinoma & & & & \\
\hline 5 & 50 & $\mathbf{M}$ & Spindle cell carcinoma & Medullary carcinoma & & & $\equiv$ \\
\hline 6 & 24 & $\mathbf{F}$ & Anaplastic carcinoma & Medullary carcinoma & & & 으 \\
\hline 7 & 37 & $\mathbf{F}$ & Anaplastic carcinoma & Medullary carcinoma & & & \\
\hline 8 & 62 & $\mathbf{M}$ & Carcinoma & Medullary carcinoma & $\begin{array}{l}\text { One brother had thyroid } \\
\text { carcinoma }\end{array}$ & & 음 \\
\hline 9 & 33 & $\mathbf{M}$ & $\begin{array}{l}\text { Poorly differentiated } \\
\text { follicular carcinoma }\end{array}$ & & & $\begin{array}{l}\text { Nodular enlargement, } \\
\text { ? adenoma of the only } \\
\text { parathyroid found }\end{array}$ & N \\
\hline 10 & 31 & $\mathbf{M}$ & Medullary & & $\begin{array}{l}\text { Son (case } 11 \text { ) and grand- } \\
\text { daughter both had } \\
\text { medullary carcinoma }\end{array}$ & Adenoma of parathyroid & $\begin{array}{l}\text { ల } \\
\text { W }\end{array}$ \\
\hline 11 & 22 & $\mathbf{M}$ & Medullary & & See case 10 & & 이 \\
\hline 12 & 29 & $\mathbf{F}$ & $\begin{array}{l}\text { Moderately differentiated } \\
\text { adenocarcinoma }\end{array}$ & & & & 을 \\
\hline 13 & 28 & $\mathbf{F}$ & Medullary & & & $\begin{array}{l}\text { Multiple chief cell } \\
\text { adenomas of three para- } \\
\text { thyroids. Clinical ? } \\
\text { hyperparathyroidism }\end{array}$ & \begin{tabular}{l}
$\mathscr{C}$ \\
$\stackrel{D}{D}$ \\
\hdashline
\end{tabular} \\
\hline 14 & 27 & $\mathbf{M}$ & Carcinoma & Medullary carcinoma & & $\begin{array}{l}\text { Three enlarged para- } \\
\text { thyroids, two with } \\
\text { adenomas; raised serum } \\
\text { calcium }\end{array}$ & 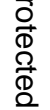 \\
\hline $\begin{array}{l}15 \\
16\end{array}$ & $\begin{array}{l}14 \\
34\end{array}$ & $\begin{array}{l}\mathbf{F} \\
\mathbf{F}\end{array}$ & $\begin{array}{l}\text { Medullary } \\
\text { Medullary }\end{array}$ & & & & $\frac{2}{\sigma}$ \\
\hline 17 & 19 & $\mathbf{F}$ & Medullary & & $\begin{array}{l}\text { Father had medullary } \\
\text { carcinoma }\end{array}$ & & 응 \\
\hline
\end{tabular}


cases in nine families. Among the reports since then is one study of a large kindred by Tisherman, Gregg, and Danowski (1962), who found seven cases among 199 relatives studied. In the series of cases reviewed now, six of the 17 cases have a family history of phaeochromocytoma, among them a father and son.

The thyroid and parathyroid findings in these cases are set out in Table II. The mean age at diagnosis of the thyroid carcinoma was 32 , and the longest follow-up was 24 years. The original histological description of the thyroid tumour was papillary in one case, anaplastic in two cases, medullary (or solid with amyloid stroma, an equivalent term) in six cases, and a variety of descriptions in the remaining seven cases. Through the kindness of the authors and pathologists concerned, sections from five of this last group were sent for review, and all were found to be typical medullary carcinomas, with amyloid deposition in the stroma (Fig. 1). Thus 11 of the 17 cases are definitely of the medullary type, while in one case (no. 3) the histological description is strongly suggestive of medullary carcinoma.

A family history of thyroid carcinoma was present in four of the 17 cases. The tumour in each of the propositi and in four of the five relatives was

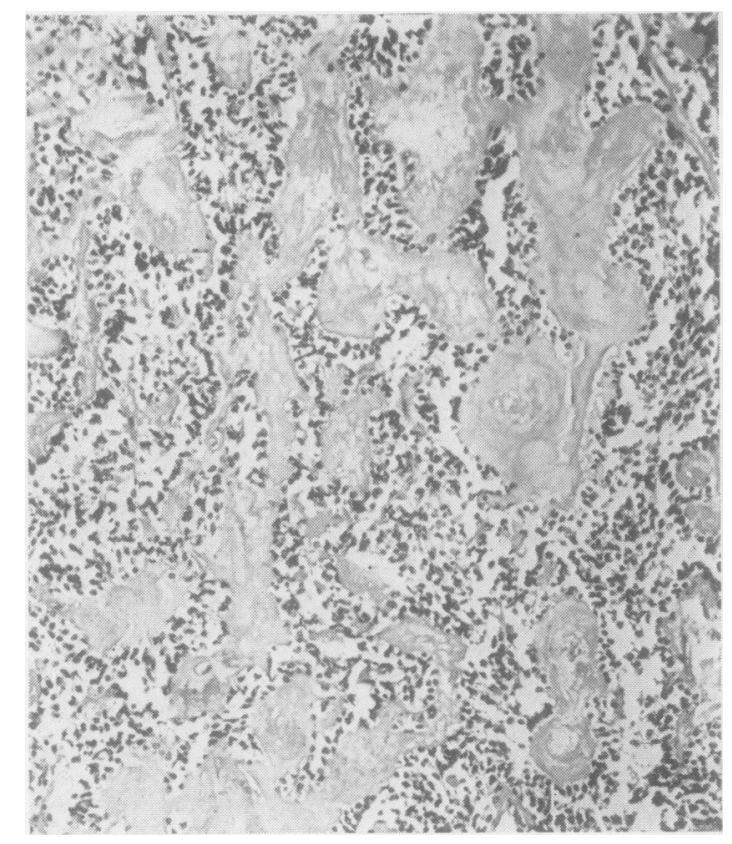

FIG. 1. An example of the histology of the thyroid tumour from one of the cases reviewed. The sheets of tumour cells are separated by areas of deposition of hyaline material shown to be amyloid by Congo red and thioflavine $T$ techniques. Haematoxylin and eosin $\times 120$. of the medullary type. In one other case there was aृ family history of thyroidectomy for unknown reasons. In four cases enlarged or adenomatous parathyroids were noted; two of these cases showe clinical evidence of hyperparathyroidism.

Cases 16 and 17 are of especial interest because both also showed evidence of multiple neura厉 tumours. Full details of these cases will be pub $\frac{0}{-}$ lished elsewhere. No similar findings were mentioned? in any of the other cases.

\section{DISCUSSION}

The details of these cases show that as a group they differ from the average patient with either phaeo 00 chromocytoma or thyroid carcinoma in a number of important ways. The major adrenal points are the्ల frequency of bilateral phaeochromocytoma, 10 oub of 17 cases, and the frequency of a family history of phaeochromocytoma. These findings are linked $\vec{z}$ because previous studies (Hume, 1960) have shown that adults with familial phaeochromocytoma havebilateral tumours in about half the cases. The trueo number of cases with a family history is likely to be greater than the figure given, and the number of cases with bilateral phaeochromocytoma is also likelys to be greater than 10 out of 17 . The higher incidences of bilateral tumours in the necropsied cases haso already been noted.

The major point in the thyroid findings is the frequency with which the histological type of the tumour is medullary carcinoma. This type of car cinoma was first described by Hazard, Hawk, and्र Crile (1959), as a tumour characterized by a soliक non-follicular histological pattern, the presence of amyloid in the stroma, and a high incidence of lymph node metastases. Out of the nine cases of thyroid carcinoma and phaeochromocytoma described since then, six have been medullary. Five cases have been reviewed; in each of them the diagnosis of medullary? carcinoma was made. Medullary carcinoma is a rare type of thyroid tumour, forming about $6.5 \%$ of alE cases of thyroid carcinoma (Woolner, Beahrs, Black ${ }_{\sigma}^{N}$ McConahey, and Keating, 1961), so that its presencou in at least 11 out of 17 cases of thyroid carcinoma is obviously significant. The finding of a family history ${ }^{\omega}$ of thyroid carcinoma in four of the cases is again correlated with the histological type. The fouf patients from three families noted in Table II whop showed a family history of thyroid carcinoma all had medullary carcinoma, as did four of the five relatives $\frac{0}{0}$ A familial history of thyroid carcinoma, in contrast to goitre or thyroiditis, is extremely rare. One family described by Friedell, Carey, and Rosen(1962), com气 prised a mother and two daughters with thyroide carcinoma; the type in the mother was not known 
in one daughter the histology was described as atypical carcinoma, in the other as medullary carcinoma. These findings suggest, that in strong contrast to other types of thyroid carcinoma, medullary carcinoma may be familial.

The significance of this association of thyroid carcinoma and phaeochromocytoma is heightened by the finding in the majority of cases that the thyroid cancer is of the medullary type. Sipple (1961) calculated that the incidence of thyroid carcinoma in patients with phaeochromocytoma was 14 times higher than that of the general population. Despite all the drawbacks in this type of calculation, it is obvious that the relative incidence of medullary carcinoma in cases of phaeochromocytoma is likely to be much greater than the figure quoted by Sipple. It is suggested that the association between phaeochromocytoma and thyroid carcinoma is specifically with medullary carcinoma of the thyroid.

The reasons for the occurrence of this combination of tumours are far from clear. Sipple suggested that high levels of epinephrine might possibly lead to thyroid cancer, perhaps by a thyroid-stimulating hormone effect. This seems very unlikely on a number of grounds. The clinical evidence for thyroid carcinoma preceded that for phaeochromocytoma by many years in several cases. The types of thyroid neoplasm in which raised thyroid-stimulating hormone effects are thought to play a part are not medullary; the thyroid tumours in dyshormonogenesis are follicular in type, while in radiation carcinogenesis in children the thyroid tumour is usually papillary. The cases quoted in which a family history of medullary carcinoma was found make it extremely unlikely that either tumour led to the production of the other. It seems far more plausible that the basis for the occurrence of these two tumours is genetically determined. This is already known to be true for some cases of phaeochromocytoma, where those with bilateral tumours frequently have a family history of phaeochromocytoma and in a number of them the stigmata of von Recklinghausen's neurofibromatosis are seen.

The association of phaeochromocytoma and von Recklinghausen's disease is explicable because the origin of the adrenal medulla is from neural crest, and von Recklinghausen's disease is a neuroectodermal disorder. Logically the finding of a high incidence of medullary carcinoma of the thyroid in cases of phaeochromocytoma and also the occurrence of two cases of multiple neural tumours with both medullary carcinoma of the thyroid and phaeochromocytoma should raise the possibility that medullary carcinoma of the thyroid is neuroectodermal in origin. The thyroid epithelial cells are derived from endoderm, but are we right in assuming that medullary carcinoma of the thyroid is derived from thyroid epithelium? A number of peculiarities of medullary carcinoma have already been pointed out; it is associated with amyloid deposition in the stroma; it does not form colloid, and follicles or papillae do not seem to occur. It is a very clear-cut entity, even though a number of histological patterns may be seen. Russell, Ibanez, Clark, and White (1963) comment that medullary carcinoma may resemble various neural or paragangliomatous tumours, and also note that transition to true papillary or true follicular growth is never observed. It seems therefore that there is little direct evidence that medullary carcinoma of the thyroid arises from the thyroid epithelial cell. It is at least possible that it is derived from a cell of neuroectodermal origin.

The findings in the parathyroids of these cases are of considerable interest, and complicate the situation still further. In four cases nodular enlargement or adenoma formation was noted in the parathyroids, and in two of these there was some clinical evidence of hyperparathyroidism. Manning, Molnar, Black, Priestley, and Woolner (1963) described their case as one of multiple chief cell adenomas of the parathyroid, and it seems likely that this was also true in the case of Finegold and Haddad (1963). There seems no chance that these parathyroid tumours are of neuroectodermal origin, and their occurrence weakens the argument for this type of origin for the thyroid tumours. However, the medullary carcinoma of thyroid is such an unusual tumour that the possibility of an unusual origin should still be left open.

The occurrence of parathyroid hyperplasia and adenoma formation together with phaeochromocytoma and thyroid carcinoma led Manning et al. (1963) to refer to their findings as a variant of the multiple endocrine adenoma syndrome. While obviously the patient did have multiple endocrine tumours, it seems likely that this association of phaeochromocytoma and thyroid carcinoma, with parathyroid hyperplasia in some cases, is quite distinct from the syndrome characterized by pituitary, pancreatic, parathyroid, and adrenal cortical hyperplasia and adenoma formation. No case has been traced which showed this combination of tumours and also phaeochromocytoma, and only one case with a thyroid carcinoma (Schmid, Labhart, and Rossier, 1961) was found in a survey of the literature. This case showed a nodular colloid goitre with one atypical area which was stated to be a 'Langhans' type carcinoma. None of the large number of cases in one family studied by Wermer (1963) showed evidence of either phaeochromocytoma or thyroid carcinoma.

It is important that the term 'multiple endocrine 
adenoma' should not be used in a way that hinders the understanding of endocrine tumour associations other than those originally described under this term. The association of pituitary, parathyroid, pancreatic, and adrenal cortical tumours seems to originate in a diffuse hyperplasia of these glands, with eventual adenoma foundation. The terms 'pluriglandular syndrome' or 'Lloyd's syndrome' have also been used in referring to this condition. The association of thyroid carcinoma and phaeochromocytoma should be clearly differentiated from this. On reviewing the reported cases the salient features of this association are the frequency with which the phaeochromocytomas are bilateral, the frequent finding of a family history for phaeochromocytoma and thyroid carcinoma, and the fact that in the majority of the reported cases the thyroid carcinoma is of the medullary type. The coincidence that medullary carcinoma of the thyroid is associated with tumours of the adrenal medulla leads to the suggestion that the term 'medullary tumour syndrome' be used as a convenient abbreviated description of this association until a better understanding of its true nature is achieved.

\section{ADDENDUM}

Since this paper was submitted for publication several other relevant cases have come to the author's attention. Nourok (1964) described bilateral phaeochromocytoma and thyroid carcinoma in a mother and daughter; the thyroid carcinoma was definitely of the medullary type in the daughter, and possibly so in the mother.

Aubert, Pedinielli, Carlopino, Detolle, Sudaka, and Armand (1964) describe a woman of 30 with a goitre and bilateral phaeochromocytoma; the patient's sister had a thyroid carcinoma.

Dr. R. C. Horn has kindly provided details of an unpublished case from Detroit; this patient of 46 was found to have bilateral phaeochromocytoma, a medullary thyroid carcinoma with widespread metastases, and a parathyroid adenoma.

In the large family with many cases of phaeochromocytoma described by Smits and Huizinga (1961) a second patient has developed thyroid car- cinoma; the type is unrecorded (Smits, persona communication, 1964).

The addition of this information brings the number of case reports of phaeochromacytoma and thyroid carcinoma to 21 . The histological type of thyroid carcinoma is definitely medullary in 13 an probably medullary in two. In 14 of the 21 patients the phaeochromocytomas were bilateral. A family history of phaeochromocytoma was evident in nino and a family history of thyroid carcinoma in eight of the 21 cases.

The help and encouragement of Professor I. Doniach gratefully acknowledged. Particular thanks are due Drs. J. C. Dick, M. J. Finegold, P. Freedman, J. de Graeff, H. E. Schornagel, M. Smits, and Professor R. We Scarff for their kindness in allowing me to review the histological findings of the reported cases.

\section{REFERENCES}

Aubert, L., Pedinielli, L., Carlopino, C., Detolle, P., Sudaka, P., arie Armand, P. (1964). Bull. Soc. méd. Hop. (Paris), 115, 891.

Beer, E., King, F. H., and Prinzmetal, M. (1937). Ann. Surg., 106, 85

Cushman, P. Jr. (1962). Amer. J. Med., 32, 352 Dick, J. C., Ritchie, G. M., and Thompson, H. (1955). J. clin. Path

De Graeff, J., Muller, H., and Moolenaar, A. J. (1959). Acta me度 scand., 164, 419.

Eisenberg, A. A., and Wallerstein, H. (1932). Arch. Path., 14, 818.

Finegold, M. J., and Haddad, J. R. (1963). Arch. Path., 76, 449.

Freedman, P., Moulton, R., Rosenheim, M. L., Spencer, A. G., ant Willoughby, D. A. (1958). Quart. J. Med., 27, 307.

Friedell, G. H., Carey, R. J., and Rosen, H. (1962). Cancer (Philad 15, 241.

Hayles, A. B., Johnson, L. M., Beahrs, O. H., and Woolner, L. $\overrightarrow{\text { E }}$ (1963). Amer. J. Surg., 106, 735.

Hazard, J. B., Hawk, W. A., and Crile, G. Jr. (1959). J. clin. Endocr $19,152$.

Hume, D. M. (1960). Amer. J. Surg., 99, 458.

Manning, P. C. Jr., Molnar, G. D., Black, B. M., Priestley, J. T., and Woolner, L. B. (1963). New Eng. J. Med., 268, 68.

Muntz, H. H., Ritchey, J. O., and Gatch, W. D. (1947). Ann. inter Med., 26, 133.

Nourok, D. S. (1964). Ibid., 60, 1028.

Rothermich, N. O. (1952). Jbid., 36, 157.

Russell, W. O., Ibanez, M. L., Clark, R. L., and White, E. C. (19639 Cancer (Philad.), 16, 1425.

Sahay, U. (1962). Brit. med. J., 1, 1391.

Schmid, J. R., Labhart, A., and Rossier, P. H. (1961). Amer. J. Med̋ 31, 343.

Sipple, J. H. (1961). Amer. J. Med., 31, 163.

Smits, M., and Huizinga, J. (1961). Acta genet. (Basel), 11, 137.

Tisherman, S. E., Gregg, F. J., and Danowski, T. S. (1962). J. Amox) med. Ass., 182, 152.

Wermer, P. (1963). Amer. J. Med., 35, 205.

Williams, E. D., and Pollock, D. J. (1964). In preparation.

Woolner, L. B., Beahrs, O. H., Black, B. M., McConahey, W. M., and Keating, F. R. Jr. (1961). Amer. J. Surg., 102, 354.$$
\text { กิ }
$$
오.

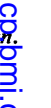

